\title{
PENINGKATAN KEMAMPUAN MOTORIK KASAR ANAK USIA 4-5 TAHUN MELALUI PERMAINAN ULAR TANGGA
}

\author{
Ellinawati ${ }^{1}$, Fitria Sari ${ }^{2}$, Ayu Mustika Sari ${ }^{3}$ \\ Fakultas Keguruan dan Ilmu Pendidikan, Universitas Dharmas Indonesia \\ Email : eli29021996@gmail11.com,fitriasari011115@gmail.com², ayumustikasari10@gmail.com ${ }^{3}$ \\ Ellinawati, Fitria Sari, Ayu Mustika Sari. (2021). Peningkatan Kemampuan Motorik Kasar Anak Usia 4-5 Tahun \\ Melalui Permainan Ular Tangga. Jurnal Pelita PAUD, 6(1), 148-154. \\ doi: https://doi.org/10.33222/pelitapaud.v4i1.780
}

Abstrak: Penelitian ini bertujuan untuk upaya meningkatkan kemampuan motorik kasar anak usia $4-5$ tahun di PAUD Al izza Plus Sungai rumbai Kabupaten Dharmasraya. Jenis penelitian ini adalah penelitian tindakan kelas yang dilakukan dalam II siklus, subjek dalam penelitian ini adalah peserta didik kelompok mandiri PAUD Al Izza Plus Sungai Rumbai Kabupaten Dharmasraya Tahun ajaran 2020/2021 yang berjumlah 9 anak yang terdiri atas 2 laki-laki dan 7 perempuan. Pengumpulan data dilakukan melalui Observasi dan dokumentasi. Teknik analisis di lakukan dengan menggunakan data kuantitatif. Hasil penelitian ini menujukan bahwa keterampilan motorik kasar anak usia dini dapat ditingkatkan melalui permainan ular tangga raksasa. Peningkatan kemampuan motorik kasar anak secara keseluruhan sebelum adanya tindakan meningkat dari 35\% dengan kategori MB(Mulai berkembang), menjadi 55\% dengan kategori BSH dan BSB pada siklus I, menjadi $80 \%$ dengan kategori BSH dan BSB pada siklus II.

Kata kunci: Motorik Kasar, Permainan Ular Tangga, Anak kelompok Mandiri

Abstract: This study aims to improve gross motor skills of children aged 4-5 years in PAUD Al Izza Plus Sungai Rumbai, Dharmasraya Regency. This type of research is classroom action research which is carried out in cycle II, the subjects in this study are the independent group students of PAUD Al Izza Plus Sungai Rumbai Dharmasraya Regency for the 2020/2021 academic year, totaling 9 children consisting of 2 boys and 7 girls. Data collection is done through observation and documentation. The analysis technique is carried out using quantitative data. The results of this study indicate that the gross motor skills of early childhood can be improved through the game of giant snakes and ladders. The overall improvement of children's gross motor skills before the action increased from $35 \%$ in the $M B$ category (Starting to develop), to 55\% in the BSH and BSB categories in the cycle I, to $80 \%$ in the BSH and BSB categories in the cycle II.

Keywords: Gross Motor Skills, Snake Ladder, Independent Group Clildren

http://jurnal.upmk.ac.id/index.php/pelitapaud 


\section{PENDAHULUAN}

Pertumbuhan pada manusia akan terus berjalan selama manusia masih mampu menghirup udara untuk bernafas dan juga beraktifitas. Begitu pun pada anak-anak. Anak- tak akan mampu berdiam diri ketika ia melihat sesuatu yang ia rasa bahwa itu hal baru dan patut untuk diketahui olehnya. Dan ia akan mencari tahu bagaimana hal baru itu bisa terjadi dan kemungkinan besar ia akan mencoba dan melakukan hal yang sama seperti hal baru yang telah ia lihat.

Pertumbuhan yang terjadi pada manusia dapat dilihat dari perubahan fisik, kognitif, dan juga perkembangan sosioemosi yang ada pada dirinya. Namun pada tulisan ini akan dijelaskan sedikit mengenai pertumbuhan fisik dan kesehatan pada masa kanak-kanak awal.

Anggota badan tumbuh dengan kecepatan yang berbeda .perlu dilihat pula bahwa tiap anak mempunyai kecepatan perkembangannya sendiri. Meskipun ada norma-norma yang dapat dipakai sebagai ukuran perkembangan normal (Santrock, 2011).

Pendidikan merupakan pilar utama dalam mengembangkan kualitas sumber daya manusia. Pendidikan sebagai pengubah sikap dan tingkah laku seseorang atau kelompok orang dalam proses mendewasakan diri melalui pengajaran dan pelatihan. Pendidikan juga merupakan suatu proses yang dilakukan manusia untuk menjadi yang lebih baik lagi. Pendidikan bisa dimanapun, kapanpun dan dengan siapapun. Melalui pendidikan manusia bisa tumbuh dan berkembang sesuai dengan didikan yang diberikan sehingga menjadi manusia yang berguna bagi bangsa dan negara. Dan pendidikan pertama yang harus ditempuh anak adalah Pendidikan Anak Usia Dini (PAUD). PAUD adalah pondasi dasar pendidikan yang diberikan kepada anak usia 0-6 tahun sebagai usaha untuk mengoptimalkan stimulasi sejak dini. PAUD memiliki peran yang sangat penting untuk mengembangkan kepribadian anak, serta untuk mempersiapkan mereka untuk memasuki jenjang pendidikan selanjutnya. Tugas utama PAUD adalah untuk mempersiapkan anak dengan memperkenalkan berbagai pengetahuan, sikap, prilaku dengan cara yang menyenangkan. PAUD sebagai tempat bermain yang indah, nyaman, dan gembira bagi anak untuk bersosialisasi dengan teman sebayanya.

Tujuan dari PAUD itu sendiri membantu mengembangkan potensi dan 6 aspek yang ada didalam diri anak. Anak usia dini adalah individu yang memiliki sifat yang unik dalam proses pertumbuhan dan perkembangannya. Anak usia dini memiliki potensi yang ada didalam diri anak masing masing sehingga pendidik harus membantu menggali potensi yang ada didalam diri anak. Didalam diri anak memiliki aspek aspek yang harus dikembangkan sejak usia dini yaitu salah satunya aspek perkembangan motorik. Motorik kasar didefinisikan sebagai gerakan tubuh yang menggunakan otot-otot besar atau sebagian besar atau seluruh anggota tubuh yang dipengaruhi oleh kematangan anak itu sendiri (Hidayati, 2013). Kemampuan motoric kasar merupakan kemampuan untuk menggunakan otot-otot besar pada tubuh yang digunakan antara lain untuk berjalan, berlari, dan mendaki. Anak anak prasekolah membuat kemajuan yang besar dalam keterampilan motorik kasar seperti berlari, melompat, yang melibatkan penggunaan otot besar (Imani, 2017). Keterampilan motorik kasar adalah gerakan tubuh yang menggunakan otot-otot besar atau sebagian besar atau seluruh anggota tubuh yang dipengaruhi oleh kematengan anak itu sendiri. Contoh kemampuan duduk, menendang, berlari, naik turun tangga dan sebagainya (Santrock, 2007).

Motorik kasar anak akan berkembang sesuai dengan usianya (age appropriateness). Orang dewasa tidak perlu melakukan bantuan terhadap kekuatan otot besar anak. Jika anak telah matang, maka de- ngan sendirinya anak akan melakukan gerakan yang sudah waktunya untuk dilakukan. Misalnya seorang anak usia 6 bulan belum siap duduk sendiri, maka orang dewasa tidak perlu memaksakan dia duduk di sebuah kursi. (Bulan \& Puspita, 2013). Perkembangan motorik sangat dipengaruhi oleh organ otak. Otak lah yang mensetir setiap gerakan yang dilakukan anak. Semakin matangnya perkembangan system syaraf otak yang mengatur otot memungkinkan berkembangnya kompetensi atau kemampuan motorik anak. Perkembangan motorik anak dibagi menjadi dua yaitu keterampilan atau gerakan kasar seperti berjalan, berlari, mmelompat, naik 
turun tangga, keterampilan motorik halus atau keterampilan manipulasi seperti menulis, menggambar, memotong, melempar dan menagkap bola serta memainkan bendabenda atau alat-alat mainan (Hurlock, 1978)., bermain dan bermain adalah segalanya. Dari keterampilan hidup dasar hingga fungsi eksekutif otak manusia, semuanya paling baik dipelajari melalui permainan, melalui permainan anak-anak terhubung dengan minat mereka sendiri, belajar membuat keputusan, belajar untuk menangani emosi mereka, berteman, dan yang paling penting, mendapatkan kebahagiaan.

permainan merupakan kegiatan yang dirancang secara matang dan bertujuan untuk meningkatkan berbagai kemampuan khusus melalui pengalaman belajar(Permendiknas, 2018). Permainan bagi anak merupakan seperangkat alat bereksplorasi menjelajahi dunianya dari yang tidak dikenal sampai pada tahapan mengetahui dan dari yang dapat diperbuatnya sampai mampu melakukannya secara mandiri. Permainan adalah seperangkat konsep, sistem, prosedur yang mengatur anak anak dalam melakukan kegiatan bermain (Yus, 2011). Melalui permainan kegiatan bermain dapat teridentifikasi dengan baik, dikakukan dengan prosedur yang telah ditentukan dan sistematis. Sedangkan aktifitas permainan yang memiliki nilai edukasi disebut sebagai permainan edukatif (Albert, 1977). Sebagian orang tua maupun pendidik memiliki harapan bahwa anaknya dapat berkembang dengan baik sesuai dengan tahap perkembangan yang semestinya akan dilalui oleh anak khususnya perkembangan motorik kasar. Begitupun guru di PAUD Al Izza Plus Sungai Rumbai Kabupaten Dharmasraya sangat mengharapkan aspek perkembangan motorik kasar anak berkembang sangat baik. Selain itu guru juga memberikan bimbingan untuk mengembangkan aspek perkembangan motorik kasar anak. Guru berharap 75\% anak berada pada tahap Berkembang Sesuai Harapan (BSH) dan Berkembang Sangat Baik (BSB) dari semua indikator perkembangan motorik kasar.

Berdasarkan hasil observasi penulis di PAUD Al Izza Plus Sungai Rumbai Kabupaten Dharmasraya pada hari Senin tanggal 25 Januari 2021. Aspek perkembangan anak belum berkembang sesuai dengan tahap usianya. Aspek perkembangan anak masih rendahkurang disebabkan guru memiliki keterbatasan permainan yang mampu mengembangkan aspek perkembangan motorik kasar anak, kurangnya kegiatan pembelajaran yang dapat menstimulasi aspek perkembangan motorik kasar anak, kurang melakukan kegiatan pembelajaran yang dapat menstimulasi aspek perkembangan motorik kasar anak dan kurangnya APE (Alat Permainan Edukatif) di luar kelas yang dapat menstimulasi aspek perkembangan motorik kasar anak. Berdasarkan latar belakang di atas, penulis tertarik untuk melakukan penelitian dengan menggunakan permainan yang mampu membangkitkan semangat, rasa ingin tahu, dan percaya diri anak maupun mengembangkan kemampuan motorik kasar anak secara maksimal. Berdasarkan masalah tersebut maka penulis berupaya menyelesaikan masalah rendahnya pencapaian perkembangan motorik kasar anak melalui permainan Ular Tangga Raksasa.

\section{METODE PENELITIAN}

\section{Jenis Penelitian}

Jenis penelitian yang dilakukan adalah Penelitian Tindakan Kelas (PTK). Untuk melakukan penelitian guru perlu memahami permasalahan yang ada didalam kelas sehari hari yang di temui sewaktu melaksanakan proses pembelajaran.

\section{Waktu dan Tempat Penelitian}

Tempat penelitian merupakan sasaran ilmiah untuk mendapatkan data dengan tujuan dan kegunaan tertentu tentang sesuatu hal yang objektif.Penelitian Tindakan Kelas (PTK) dilaksanakan di PAUD Al Izza Plus Sungai Rumbai Kabupaten Dharmasraya yang terletak di Jorong Koto Mulia, Nagari Kurnia Selatan, Kec. Sungai Rumbai, Kab. Dharmasraya. Waktu Penelitian Tindakan Kelas ini dilaksanakan pada semester genap Tahun Ajaran 2020/2021.

\section{Subjek Penelitian}

Subjek penelitian merupakan suatu atribut atau sifat atau nilai dari orang. Subjek penelitian yang dilakukan oleh penelitian tindakan kelas ini dilakukan di kelas Mandiri dengan jumlah siswa sebanyak 9 siswa yang terdiri dari 2 siswa laki-laki dan 7 siswa perempuan usia 5-6 tahun. Subjek penelitian ini dilihat dari kemampuan aspek motorik 
P ISSN 2548-6284 E ISSN 2615-0360

Vol. 6 No. 1 Desember 2021

kasar anak yang belum berkembang sesuai dengan harapan.

\section{Prosedur}

Prosedur pelaksanaan penelitian dilakukan secara bersiklus yang dimulai dari siklus pertama, siklus kedua sangat ditentukan oleh hasil refleksi.Menurut (Indrawati \& Rahmah, 2020), Tahapan dalam satu putaran siklus terdiri dari terdiri dari empat komponen yaitu perencanaan (planning), tindakan (acting), pengamatan (observing), dan refleksi (reflecting).

Data, Intrumen, dan Teknik Pengumpulan Data

Dalam penelitian ini instrumen yang digunakan peneliti adalah lembar observasi (chek list) dan lembar penilaian hasil belajar anak. Teknik pengumpulan data adalah dengan cara wawancara, observasi dan dokumentasi Pada penelitian ini peneliti menggunakan dua teknik yaitu : teknik observasi dan teknik dokumentasi.

\section{Teknik Analisis Data}

Data yang sudah dikumpulkan melalui observasi, dianalisis menggunakan rumus presentase sederhana menurut (Muflikha, 2013) yaitu:

$$
P=\frac{f}{n} \times 100 \%
$$

Ket :

$$
\begin{array}{ll}
\mathrm{P} & =\text { Persentase yang diperlukan } \\
\mathrm{F} & \text { = Frekuensi nilai siswa } \\
\mathrm{N} & \text { = Jumlah anak dalam suatu } \\
\text { kelas } &
\end{array}
$$

\section{HASIL DAN PEMBAHASAN}

Keterampilan motorik kasar adalah gerakan tubuh yang menggunakan otot-otot besar atau sebagian besar atau seluruh anggota tubuh yang dipengaruhi oleh kematengan anak itu sendiri (Hurlock, 1978). Contoh kemampuan duduk, menendang, berlari, naik turun tangga dan sebagainya (Santrock, 2007). Perkembangan motorik sangat dipengaruhi oleh organ otak. Otak lah yang mensetir setiap gerakan yang dilakukan anak. Semakin matangnya perkembangan system syaraf otak yang mengatur otot memungkinkan berkembangnya kompetensi atau kemampuan motorik anak. Perkembangan motorik anak dibagi menjadi dua yaitu keterampilan atau gerakan kasar seperti berjalan, berlari, mmelompat, naik turun tangga, keterampilan motorik halus atau keterampilan manipulasi seperti menulis, menggambar, memotong, melempar dan menagkap bola serta memainkan benda- benda atau alat-alat mainan (Hurlock, 1978). , bermain dan bermain adalah segalanya. Dari keterampilan hidup dasar hingga fungsi eksekutif otak manusia, semuanya paling baik dipelajari melalui permainan, melalui permainan anakanak terhubung dengan minat mereka sendiri, belajar membuat keputusan, belajar untuk menangani emosi mereka, berteman, dan yang paling penting, mendapatkan kebahagiaan.

permainan merupakan kegiatan yang dirancang secara matang dan bertujuan untuk meningkatkan berbagai kemampuan khusus melalui pengalaman belajar. Permainan bagi anak merupakan seperangkat alat bereksplorasi menjelajahi dunianya dari yang tidak dikenal sampai pada tahapan mengetahui dan dari yang dapat diperbuatnya sampai mampu melakukannya secara mandiri. Permainan adalah seperangkat konsep, sistem, prosedur yang mengatur anak anak dalam melakukan kegiatan bermain. Melalui permainan kegiatan bermain dapat teridentifikasi dengan baik, dikakukan dengan prosedur yang telah ditentukan dan sistematis. Sedangkan aktifitas permainan yang memiliki nilai edukasi disebut sebagai permainan edukatif (Albert, 1977).

Berdasarkan hasil observasi pada peningkatan perkembangan motorik kasar anak antara siklus I pertemuan ke-2 dan siklus II pertemuan ke-2 mengalami peningkatan. Pada siklus I pertemuan ke-2 kemampuan motorik kasar anak baru mencapai $65 \%$ berada pada BSH dan BSB, sedangkan pada siklus II pertemuan ke-2 anak mengalami peningkatan mencapai $82 \%$ berada pada tahap BSH dan BSB. yang kemudian disajikan dalam bentuk tabel rekapitulasi penilaian per siklus sebagai berikut :

Tabel 1. Hasil Perbandingan siklus I dan Siklus II

\begin{tabular}{lll}
\hline \multicolumn{2}{l}{ Presentasi yang di peroleh } & \multirow{2}{*}{ Kriteria } \\
\cline { 1 - 2 } SIKLUS I & SIKLUS II & \\
PK-2 & PK-2 & Meningkat \\
$65 \%$ & $82 \%$ & \\
\hline
\end{tabular}

Berdasarkan pengelolaan data yang telah dilakukan, bahwa melalui kegiatan bermain melalui permainan ular tangga raksasa dapat 
meningkatkan kemampuan motorik kasar dan dapat dilihat berdasarkan hasil pertemuan keseluruhan pada siklus I dan II. Meskipun demikian keberhasilan dalam meningkatkan kemampuan motorik kasar tidak terjadi secara langsung melainkan secara bertahap melalui berbagai tindakan hingga mencapai indikator keberhasilan.

Menurut(Putra, 2017)motorik kasar adalah bagian dari aktivitas yang mencakup keterampilan otot otot besar, gerakan ini lebih menuntut kekuatan fisik dan keseimbangan. Gerakan motorik kasar melibatkan aktifitas tangan dan kaki. Berbagai gerakan motorik kasar anak yang dicapai anak anak sangat berguna bagi kehidupan kelak, seperti merangkak, berjalan, berlari dan melompat (Imani, 2017). Perkembangan motorik bisa terjadi dengan baik apabila anak memperoleh kesempatan yang cukup besar untuk melakukan aktivitas fisik dalam bentuk gerakan-gerakan yang melibatkan seluruh tubuh.

Cara permainannya dilakukan berkelompok dengan langkah-langkah sebagai berikut: 1) permainan paling sedikit diikuti oleh dua anak dan maksimal 4 anak, 2) guru atau rang tua menyebutkan nama alat-alatnya, 3) guru atau orang tua menyampaikan tata tertib bermain, 4) awali dengan sueet atau hompimpah untuk menentukan siapa yang akan pertama memainkan dadu, 5) anak yang pertama mendapat giliran akan mengocok dan melemparkan dadu, 6) anak menjalankan anak dadu sesuai dengan perintah yang ada pada titik titik dadu, misal titik dua maka akan menjalankan dadu dari START dua langakah ke kanan sesuai urutan angka, 7) permainan dilakukan secara bergantian, 8) langkah anak dadu selanjutnya mengikuti pada capaian langkah anak dadu sebelumnya, 9) pemenang yang berhasil adalah pemain yang pertama kali selamat langkah anak dadunya di angka $60,10)$ pemenang mendapatkan reward.

Berdasarkan kemampuan yang dapat dikembangkan dengan meningkatkan motorik kasar anak melalui permainan ular tangga raksasa dapat dijabarkan keberhasilan siklus I dan siklus II bahwa, sikap semangat anak dalam mengikuti kegiatan terdapat peningkatan yang signifikan dari siklus I dan siklus II. Dilihat dari aktivitas guru pembelajaran pada siklus II sudah berjalan dengan baik dan berhasil. Dari perkembangan kemampuan motorik kasar anak dengan permainan ular tangga raksasa dapat meningkat dari siklus I ke siklus II yaitu guru lebih bersemangat membimbing anak dan memotivasi anak, lebih mendampingi dan memperhatikan anak yang mengalami kesulitan dalam pembelajaran, guru merancang pembelajaran yang lebih menarik lagi. Peneliti memberikan semangat berupa motivasi kepada anak yang sulit mencapai indikator yang diharapkan. Peningkatan kemampuan motorik kasar anak dengan permainan ular tangga raksasa tidak akan berhasil tanda didukung oleh kemampuan guru, tingkat antusias belajar anak anak juga diperkuat. Melalui siklus I terlihat kemampuan motorik kasar anak dengan permainan ular tangga raksasa belum meningkat dengan baik karena masih banyak anak tidak percaya diri dengan kemampuan yang dimilikinya tingkat keberhasilan pada siklus I ini belum mencapai pada indikator yang diharapkan, sedangkan pada siklus II ini anak yang mendapat nilai rendah berkurang, sehingga keberhasilan anak pada aspek ini mencapai indikator yang diharapkan.

Hasil penelitian menunjukan bahwa permainan ular tangga raksasa dapat merangsang anak bereksplorasi menggunakan indra penglihatan, perabaan, dan pendengaran. Dapat menstimulusi lima aspek perkembangan anak terutama dalam motorik kasar anak. Dapat mendukung terwujudnya motivasi positif pada anak. Dapat mempengaruhi kebutuhan psikologi anak seperti senang, percaya diri, dan perubahan perilaku, bersosialisasi, berkomunikasi, Dapat mengembangkan daya aktivitas anak, dan sebagai media kreativitas anak.

Berdasarkan hasil penelitian juga mengungkapkan bahwa permainan ular tangga raksasa memiliki beberapa karakteristik, diantaranya, sebagaimana yang dikemukakan oleh (Mulia, D. S., 2016) mengandung nilai pendidikan, suatu benda dikategorikan sebagai nilai edukasi apabila mengadung nilai pendidikan. Nilai yang didapat dari alat permainan ular tangga raksasa adalah mampu merangsang daya pikir anak dalam memahami cara menggunakan permainan ular tangga. Dari tiap tiap simbol gambar yang disajikan, akan mengantarkan anak untuk berpikir makna gambar tersebut. Kemudian anak 
mampu memecahkan masalah untuk mencapai tujuan akhir bebas dari covid-19, anak akan berhati hati melewati satu demi satu perilaku sehat yang harus ditaati dan yang harus dihindari. Kemudian alat permainan ular tangga ini mampu meningkatkan konsentrasi dalam mengocok dadu agar menghasilkan dan melanjutkan tangga berikutya, konsentrasi dalam melewati kotak demi kotak sesuai dengan titik dadu yang dimainkan. Hasil penelitian menunjukan bahwa permainan ular tangga dapat meningkatkan beberapa hal antara lain merangsang anak bereksplorasi menggunakan indra penglihatan, perabaan, dan pendengaran, menstimulus perkembangan motorik kasar anak. Mendukung terwujudnya motivasi positif pada anak, mempengaruhi kebutuhan psikologi anak seperti senang, percaya diri, dan perubahan perilaku, bersosialisasi, berkomunikasi. Mengembangkan daya aktivitas anak, dan media kreativitas anak (Mujahidatul Mukarromah, 2016). Permainan ular tangga raksasa ditujukan untuk anak usia 5-6 tahun sesuai dengan karakteristik anak usia 5-6 tahun, dan capaian perkembangan yaitu mengembangkan aspek kognitif, afektif dan psikomotorik. Permainan ular tangga memberikan motivasi (Mulia, 2017), merangsang anak bereksplorasi dan bereksperimen. Motivasi dan minat yang muncul pada diri anak dalam bereskplorasi dan bereksperimen merupakan faktor yang penting dan menunjang keberhasilan belajar anak. Permainan ular tangga raksasa menghadirkan rasa senang dan situasi bermain yang menyenangkan. Rasa senang anak anak yang sedang memainkan permainan ular tangga raksasa dibuktikan dengan ketertarikan mereka dalam memainkannya. Mereka tampak serius, konsentrasi dan sulit dialihkan perhatiannya pada benda atau kegiatan yang lain. Kondisi seperti ini muncul karena anak merasa nyaman dan menikmati permainannya.. Rasa senang nampak ketika berhasil naik tangga dan tiba tiba turun tangga atau naik lagi sampai benar benar selamat dan tidak dikesankan menjadi kegiatan yang membosankan dan beban (Sari, 2014). Sedangkan situasi yang menyenangkan karena dimainkan secara Bersama baik dengan guru, teman atau anggota keluarga. Menumbuhkan rasa percaya diri dan citra diri anak yang positif, dalam memainkan alat ini, anak akan mandiri melakukan permainan dengan mengocok dadu, melempar dadu dan menjalankan anak dadu dengan percaya diri dan senang. Mendorong aktivitas dan kreativitas. Aktivitas adalah sebuah energi untuk aktif mengoperasionalkan dan rasa tahu yang kuat pada anak. Anak akan berusaha ikut aktif memainkan permainan ular tangga secara dekat, sedangkan kreativitas adalah dorongan memunculkan gagasan(Dina Nur'afifah, 2019). Ketika anak bermain kadang ditemukan tiba tiba ada gagasan diluar dugaan guruPermainan ular tangga membangun pengetahuan anak, ada sesuatu yang bisa dihasilkan, yaitu konstruktif merupakan capaian perkembangan yang sudah direncakan oleh guru atau sesuatu yang dihasilkan oleh anak menuntaskan dan menyelesaikan permainan.

\section{SIMPULAN}

Hasil penelitian menunjukan bahwa permainan ular tangga raksasa dapat merangsang anak bereksplorasi menggunakan indra penglihatan, perabaan, dan pendengaran. Dapat menstimulusi lima aspek perkembangan anak terutama dalam motorik kasar anak. Dapat mendukung terwujudnya motivasi positif pada anak. Dapat mempengaruhi kebutuhan psikologi anak seperti senang, percaya diri, dan perubahan perilaku, bersosialisasi, berkomunikasi, Dapat mengembangkan daya aktivitas anak, dan sebagai media kreativitas anak. Berdasarkan hasil analisis data yang diperoleh dalam penelitian ini dapat diambil kesimpulan tentang meningkatkan kemampuan motorik kasar anak melalui permainan ular tangga raksasa di PAUD Al Izza Plus Kecamatan Sungai Rumbai Kabupaten Dharmasraya. Permainan ular tangga raksasa dapat menjadi salah satu alternatif untuk meningkatkan kemampuan motorik kasar anak melalui permainan ular tangga raksasa pada anak usia 4-5 tahun di PAUD Al Izza Plus Kecamatan Sungai Rumbai Kabupaten Dharmasraya. Melalui permainan ular tangga raksasa dapat juga mengembangkan rasa percaya diri, tanggung jawab dan semangat yang tinggi. Pemahaman anak meningkat hal ini terlihat bahwa pada pra siklus anak belum bisa melakukan gerakan tubuh sesuai dengan 
arahan dan $65 \%$ anak berada pada tahap MB setelah melakukan siklus I kemampuan motorik kasar anak baru mencapai 55\% pada tahap BSH dan BSB, pada siklus II meningkat menjadi $80 \%$ pada tahap BSH dan BSB, dapat Albert, B. (1977). Social Learning Theory. Prentice-Hall, Inc.

Bulan, B. U., \& Puspita, W. A. (2013). Pengembangan Program Stimulasi Gerak Untuk Mengoptimalkan Perkembangan Motorik Kasar. Prndidikan.

Dina Nur'afifah, L. K. dan A. D. G. (2019). MENINGKATKAN KECERDASAN KINESTETIK ANAK USIA DINI MELALUI PEMBELAJARAN TARI KIJANG. 16(229), 24-33.

Hidayati, M. (2013). Peningkatan Kemampuan Motorik Kasar Anak Melalui Permainan Bakiak. Pendidikan Usia Dini, 7, 196.

Hurlock, E. B. (1978). Child Development (6th ed.). McGraw-Hill.

Imani, F. (2017). Upaya Meningkatkan Kemampuan Motorik Kasar Anak Usia 5-6 Tahun Melalui Kegiatan Menari Animal Chicken Dance. 05, 103.

Indrawati, T., \& Rahmah, N. A. (2020). Peningkatan Kemampuan Motorik Kasar Anak Usia Dini Melalui Pembelajaran Gerak Tari Ayam. Ilmiah Pendidikan Anak Usia Dini, 3, 7.

Muflikha, E. S. (2013). Peningkatan Kemampuan Anak Mengenal Huruf Melalui Media Tutup Botol Hias Di Paud Kenanga I Kabupaten Pesisir Selatan. SPEKTRUM PLS, 1, 29.

Mujahidatul Mukarromah.

(2016). dinyatakan bahwa permainan ular tangga raksasa dapat meningkatkan kemampuan motorik kasar anak.

\section{DAFTAR PUSTAKA}

KINESTETIK ANAK USIA 5-6 TAHUN MELALUI PEMBELAJARAN TARI KREASI DI PAUD AL-JIHAD. Journal of Chemical Information and Modeling, 53(9), 1689-1699.

Mulia, D. S., \& S. (2016). Pembelajaran Berbasis Kearifan Lokal. Jurnal Ilmiah Kependidikan.

Mulia, A. (2017). Anak Usia Dini Melalui Metode Bermain Gerak. 1(1).

Permendiknas. (2018). Perkembangan Kinestetik Anak Usia 5-6 tahun (p. No. 58).

Putra, W. A. (2017). Perbandingan Alat Bermain Motorik Kasar Dan Media Motorik Halus Terhadap Perkembangan Kognitif Anak Usia 5-6 Tahun Paud Labschool Jember. Ilmiah Pendidikan PraSekolah Dan Sekolah Awal, $1,87$.

Santrock, J. W. (2007). Child Development (8th ed.). McGraw-Hill.

Santrock, J. W. (2011). Life Span Development (13th ed.). The McGraw-Hill Companies.

Sari, M. (2014). Peningkatan Kecerdasan Kinestetik Melalui Kegiatan Bermain Air. Jurnal Pendidikan Usia Dini, 8, 373-382.

Yus, A. (2011). Penilaian Perkembangan Belajar Anak Taman Kanak-kanak. Jakarta: Kencana (Jakarta). Kencana. 